\title{
Swiss Style beyond the border: Swiss graphic designers in Italy
}

Davide Fornari / Giovanni Profeta / SUPSI University of Applied Sciences and Arts of Southern Switzerland / Lugano / Switzerland

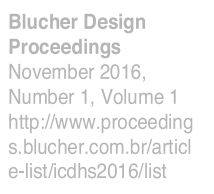

\begin{abstract}
This poster reports on the relationship between Swiss and Italian graphic design during the $20^{\text {th }}$ century, by visualizing and analyzing the community of Swiss graphic designers active in Italy. Two exhibitions held in 2012 at Museum für Gestaltung Zürich and Triennale di Milano focused on the two national scenes, with meaningful overlapping in terms of authors and artifacts. Many Swiss graphic designers are and have been active in Italy, and they represent the most influential community of foreign designers in Italy.

This poster visually presents the results of a research project conducted through literature review, archival research, and oral interviews
\end{abstract}

\section{Keywords}

Graphic design history, visual communication, Swiss Style, Italian design, information design

\section{Introduction and framework}

The relationships between Swiss and Italian graphic design have already been explored (Richter 2007; 2014), even though a number of figures and archives have only been partially investigated. The exhibitions held in 2012 at Triennale di Milano (TDM5: grafica italiana) and at Museum für Gestaltung in Zurich (100 Jahre Schweizer Grafik) represent two milestones in the history of $20^{\text {th }}$-century Italian and Swiss graphic design. In some cases the exhibitions echoed each other: same designers and, in several cases, identical projects. The Milan exhibition welcomed visitors with citations from two Swiss designers: Jan Tschichold and Lora Lamm. The Zurich exhibition featured some iconic works made for Italian brands but considered as Swiss graphic design, such as the illustrations by Lora Lamm for Pirelli.

Since the 1930s Italian and Swiss graphic design have established intense relationships, hand in hand with the cultural relations between the two countries. But while historical and critical attention for Swiss graphic design has grown over time, partly due to the very high level of quality achieved by the Swiss Style or 'International Typographic Style', "an in-depth history of [Italian] graphic design has yet to be written" (Anceschi 1981, p. 6). We can also ascribe Swiss designers active in Italy to this unbalanced historiographical landscape. While they have gained increasing critical and institutional attention through time, there are a large number of designers active in Italy who deserve further study.

Concerning the relationship between Italy and the international context, the most common critical opinion is that the 'Milanese School' or 'Italian school' was born thanks to hybridization between the Italian and Swiss graphic scenes. "The arrival of Swiss designers in Italy, on the Zurich-Milan axis, has often been seen in terms of a successful marriage between a kind of functional and calculated Swiss prose and an Italian impromptu poetic vein", writes the Italian design historian Carlo Vinti, "seen variously as resting on the balance, tension or interweaving of Nordic austerity and Mediterranean exuberance, between the mathematical order of the Swiss and the typically Italian liking for experimenting freely" (Vinti 2013: 28). As Vinti rightly puts it, "the picture becomes far more complex and nuanced" (ibidem), while the current opinion seems to be the result of two simplifications or prejudices that put Swiss and Italian graphic traditions on opposite ends of a virtual field of graphic design. 


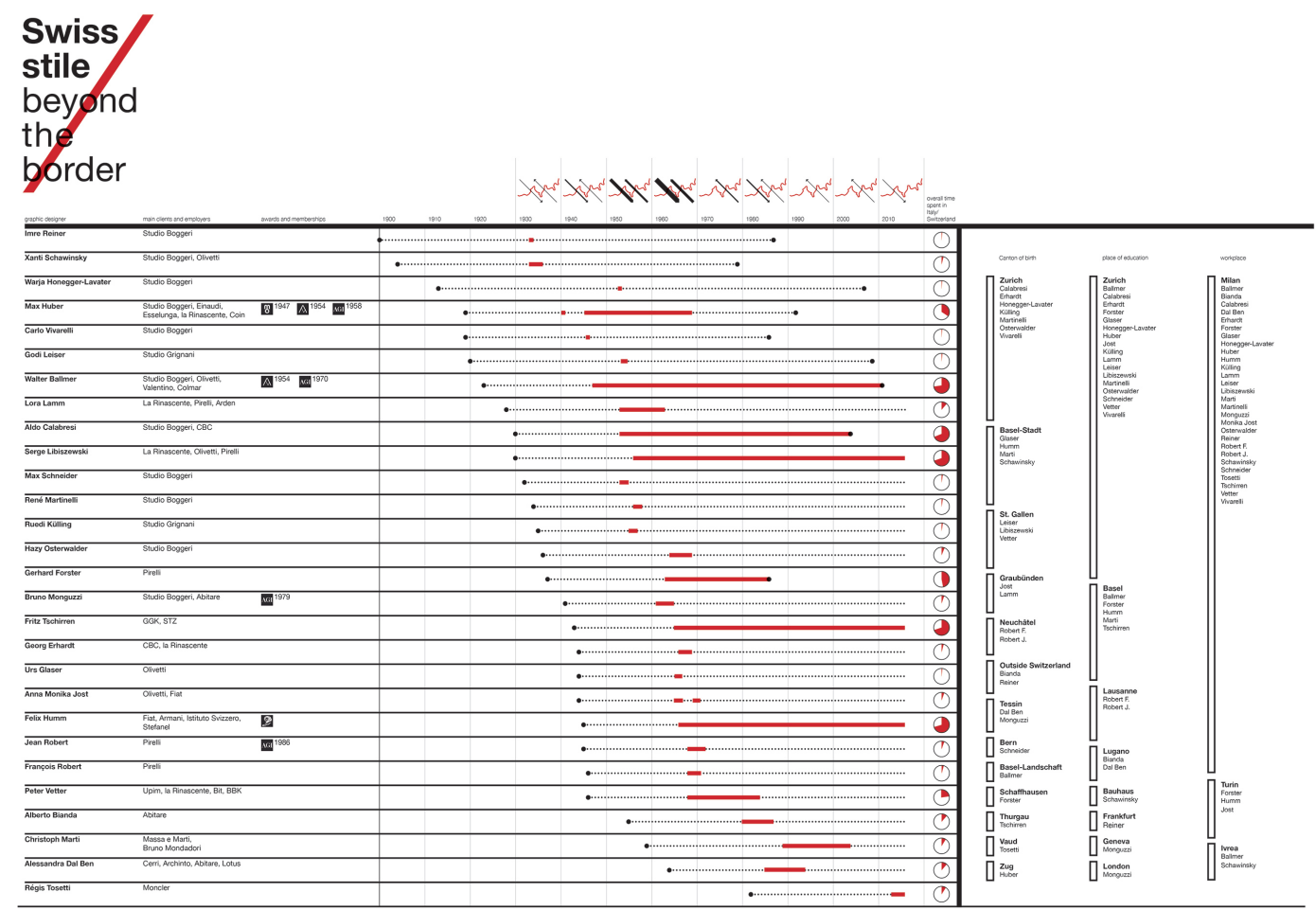

Fig. 1: Synopsis of Swiss graphic designers active in Italy since the $20^{\text {th }}$ century

\section{Methodology}

This poster and its dataset form part of a larger research project on the history of Swiss graphic design: "Swiss Graphic Design and Typography Revisited", financed by the Swiss National Science Foundation in the framework of their Sinergia program for the years 2016-2019.

The dataset was collected through the review of existing literature, the analysis of curricula vitae, archival research on digital and analogic databases, and mainly oral interviews with the people concerned or their heirs and former co-workers, typically other Swiss or Italian graphic designers.

This visualization has two goals: a. to describe life and activity of each graphic designer; $b$. to group the places where they lived in order to map the connections between Switzerland and Italy.

The dataset is composed of 28 records encompassing chronological and geographical data. The timeline and the alluvial diagram were generated through coding with the javascript library D3.js

The timeline is chronologically ordered according to designer birthdate. The alluvial diagram links names, cantons of birth, places of education and work in Italy. The height of the vertical bands shows the number of graphic designers who lived in the same city.

\section{Analysis of results and conclusions}

While this poster presents intermediate results, as more Swiss designers active in Italy remain to be interviewed, some relevant information can already be gained. First of all, the presence of Swiss graphic designers in Italy has had a Gaussian pattern, whose peak is in the past and current level is similar to the 1930s (fig. 1). The peak of the bell corresponds to the years from 1950 and 1970, a period that saw the Italian economy booming and Italian companies forging an alliance with graphic designers. These years were characterized - as in a definition by Carlo Vinti (2007) - by an 'industrial style', where Italian agencies and companies collaborated in producing successful corporate identities.

Data collected also demonstrate that Swiss graphic designers active in Italy do not solely move across the axis Zurich-Milan as their places of birth or origin are more varied and include all Swiss linguistic communities. Some of the best Swiss professionals were active on the axis Turin-Milan in crucial years. A further analysis of their works (not shown in this poster) arises doubt about the connection of Swiss graphic designers in Italy to Swiss 
style. Their works are more complex and cannot be described as Swiss style: formal and chromatic reduction, sanserif typography, privileged use of photography. In Italy, one can find Swiss graphic designers using mainly illustration (Lamm, Osterwalder), designers using serif typefaces (Huber, Monguzzi, Humm), and designers characterized by chromatic exuberance (Schawinsky, Huber, Ballmer, Jost).

Thus, it is perhaps difficult to confirm the idea that "In Italy it was difficult to separate what was Italian from what was imported from neighbouring Switzerland" (Hollis 2006, p. 255). Swiss graphic designers active in Italy represent a significant intersection of the two scenes, yet the importation of the Swiss style to Italy should be imputed to graphic designers in Italy who were mainly interested in what was happening on the Basle-Zurich axis, such as Vignelli, Waibl, Cittato, Noorda and many more. They used Helvetica, reduced the chromatic range of their posters, and used geometric shapes or photography. Indeed this transnational issue is far more complex than it has been described thus far.

\section{References}

Anceschi, G. (1981) 'll campo della grafica italiana: storia e problemi', Rassegna, vol. 3, no. 6.

Brändle, C., Gimmi, K., Junod, B., Reble, C. and Richter B. (eds.) (2014) 100 Years of Swiss Graphic Design, Zurich: Lars Müller Publishers.

Camuffo, G., Piazza, M. and Vinti C. (eds.) (2012) TDM5: grafica italiana, Mantua: Corraini.

Dradi, C. (1973) Millenovecentotrentatré: nasce a Milano la grafica moderna, Milan: Ufficio stampa del Comune di Milano.

Fioravanti, G., Passarelli, L. and Sfligiotti S. (eds.) (1997) La grafica in Italia, Milan: Leonardo Arte.

Höger, H. (2007) 'Unity in diversity: social and cultural development in Milan 1945-1970', in Richter B. (ed.) Zürich-Milano, Baden: Lars Müller Publishers, pp. 38-43.

Hollis, R. (2006) Swiss Graphic Design. The origin and growth of an international style. 1920-1965, London: Laurence King Publishers.

Hollis, R. (2012) 'The International Style and Italian Graphic Design', in Camuffo, G., Piazza, M. and Vinti C. (eds.) TDM5: grafica italiana, Mantua: Corraini, pp. 34-41.

Hollis, R. (2014) Graphic Design. A Concise History, new edition, London-New York: Thames \& Hudson.

Huber, M. (ed.) (1982) Max Huber. Progetti grafici 1936-1981, Milan: Electa.

Lamm, L. and Ossanna Cavadini N. (eds.) (2013) Lora Lamm. Graphic design in Milan 1953-1963, Cinisello Balsamo: Silvana.

Lzicar, R. and Fornari, D. (2016) Mapping Graphic Design History in Switzerland, Zurich: Triest Verlag. Monguzzi, B. (ed.) (1981) Lo studio Boggeri. 1933-1981, Milan: Electa.

Piazza, M. (ed.) (2012) Made in Italy Graphic Design. Communication and Companies design oriented 1950-1980, $2^{\text {nd }}$ edition, Milan: aiap edizioni.

Polano, S. and Vetta, P. (2003) Abecedario. La grafica italiana del Novecento, Milan: Electa.

Richter, B. (ed.) (2007) Zürich-Milano, Baden: Lars Müller Publishers.

Richter, B. (2014) 'Zurich-Milan', in Brändle, C., Gimmi, K., Junod, B., Reble, C. and Richter B. (eds.) (2014) 100 Years of Swiss Graphic Design, Zurich: Lars Müller Publishers, pp. 137-143.

Shapira, N.H. (ed.) (1979) Design Process Olivetti 1908-1978, Ivrea: Olivetti.

Sonnoli, L. (2014) 'La grammatica visiva di Franco Grignani', Domenica del Sole 24 Ore, no. 32, 2 February, p. 37.

Vinti, C. (2007) Gli anni dello stile industriale 1948-1965. Immagine e politica culturale nella grande impresa italiana, Venice: Marsilio.

Vinti, C. and Dalla Mura M. (eds.) (2013) 'Grafica, Storia, Italia', Progetto grafico, no. 24.

Waibl, H. (ed.) (1988) Alle radici della comunicazione visiva in Italia, Como: Centro di cultura grafica.

\section{Biographical note}

Davide Fornari holds a Ph.D. in Design Sciences from University luav of Venice and is a tenured teacherresearcher at SUPSI University of Applied Sciences and Arts of Southern Switzerland in Lugano, where he imparts classes of History of graphic design and typography.

Giovanni Profeta holds a Master degree in Visual and multimedia communication from University luav of Venice. He carries out applied research projects, focused on data visualization and interaction design at the Laboratory of visual culture of SUPSI. He is currently a Ph.D. candidate in Design at Politecnico di Milano. 